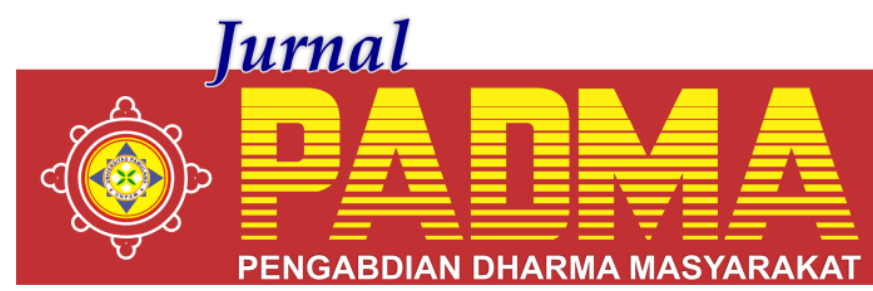

VOLUME 1, NOMOR 1, JANUARI 2021

\title{
PEMBINAAN USAHA SECARA ONLINE UNTUK MENINGKATKAN PEMASARAN DI MASA PANDEMIC COVID-19
}

\author{
${ }^{1 *}$ Munarsih, ${ }^{2}$ Rissa Hanny, ${ }^{3}$ Syarifah Ida Farida, ${ }^{4}$ Ninik Anggraini, \\ ${ }^{5}$ Heri Priyanto, ${ }^{6}$ Achmad Fauzi \\ Universitas Pamulang, Tangerang Selatan, Banten, Indonesia \\ *munarsihnanda@gmail.com
}

\begin{abstract}
Abstrak
Tujuan kegiatan adalah untuk melakukan pembinaan secara online untuk meningkatkan pemasaran di masa pandemic covid-19 pada warga yang berwirausaha di Jl. Raya Kabasiran km.2, Kecamatan Parung Panjang, Kabupaten Bogor. Hal ini karena pemerintah menyarankan untuk melakukan kegiatan tidak diluar rumah atau WFH (Work From Home) di masa pandemic covid-19. Metode pelaksanaan adalah dengan memberikan pelatihan, memberikan implementasi manajemen pemasaran, memberikan pembinaan usaha secara online untuk meningkatkan pemasaran di masa pandemic covid-19 pada warga yang berwirausaha serta memberikan warga pelatihan membuat rencana untuk meningkatkan pemasaran secara online. Ketercapaian target materi pada kegiatan PkM (Pengabdian kepada Masyarakat) dilaksanakan cukup baik, karena materi pembinaan dan implementasi manajemen pemasaran sebagai persiapan meningkatkan pemasaran secara online untuk meningkatkan perekonomian warga terutama bagi warga yang berwirausaha telah disampaikan secara keseluruhan. Secara keseluruhan kegiatan pembinaan dan implementasi manajemen pemasaran sebagai persiapan meningkatkan pemasaran secara online telah tersampaikan dengan baik terutama bagi warga yang sedang berwirausaha.
\end{abstract}

Kata Kunci : Pembinaan dan Implementasi, Manajemen Pemasaran

The aim of the activity is to provide online guidance to improve marketing during the Covid-19 pandemic for entrepreneurial citizens on Jl. Raya Kabasiran km.2, Parung Panjang District, Bogor Regency. This is because the government recommends carrying out activities not outside the home or WFH (Work From Home) during the Covid-19 pandemic. The method of implementation is to provide training, provide marketing management implementation, provide online business coaching to improve marketing during the Covid-19 pandemic to entrepreneurial citizens and provide training citizens to make plans to increase online marketing. The achievement of material targets in PkM (Community Service) activities is carried out quite well, because the material for guidance and implementation of marketing management as preparation for increasing online marketing to improve the citizen's economy, especially for entrepreneurial citizens, has been delivered in its entirety. Overall, the activities of coaching and implementing marketing management in preparation for improving online marketing have been well conveyed, especially for citizens who are entrepreneurs.

Keywords: Coaching and Implementation, Marketing Management

\section{PENDAHULUAN}

Merujuk pada peraturan pemerintah Pusat dan Pemerintah Daerah Jawa Barat di masa Pandemi Covid-19 bahwa warga dilarang keluar rumah. Hal ini bertujuan untuk mencegah penyebaran Covid-19 di daerah sekitarnya. Jawa Barat merupakan salah satu provinsi yang semakin meningkat kasus Pandemi ini, sehingga dikeluarkan Peraturan Daerah tentang Pembatasan Sosial Berskala Besar (PSBB). Melihat hal ini, maka kami melakukan kerjasama dengan perangkat desa di daerah Parung Panjang Bogor Jawa Barat untuk melaksanakan kegiatan Pengabdian kepada Masyarakat (PkM).

Dengan adanya penyebaran virus, maka akan berdampak bagi warga yang kesehariannya sebagai pedagang atau yang membuka usaha. Wirausaha merupakan pelayanan yang penghasilannya didapatkan 
dengan cara bertemu langsung dengan para konsumen atau kliennya. Berdasarkan hasil survey dan wawancara dengan warga bahwa permasalahan yang ada sekarang ini dan masih berlanjut salah satunya dikarenakan tidak dapat membuka usaha dan melayani pembeli secara langsung. Selain itu, mereka juga tidak memiliki keahlian khusus untuk kegiatan jual beli secara online.

Hal ini merupakan solusi yang diberikan dosen prodi Manajemen Universitas Pamulang terhadap para wirausaha dan para pedagang di desa Kabasiran Parung Panjang Bogor. Dengan adanya Pandemi Covid-19 mereka tidak mendapatkan penghasilan dikarenakan semuanya tidak diizinkan untuk keluar rumah. Oleh karena, itu Dosen Universitas Pamulang khususnya Program Studi Manajemen bekerjasama dengan perangkat desa memberikan pembinaan usaha secara online untuk meningkatkan pemasaran di masa pandemic covid -19 .

Kemudian, kegiatan ini membantu mereka untuk memasarkan produk mereka melalui pemasaran online. Hal ini karena pemerintah menyarankan untuk melakukan kegiatan tidak diluar rumah atau WFH (Work From Home) di daerah tersebut dan belum melaksanakan kegiatan jual beli atau promosi melalui pemasaran online.

Kegiatan PkM yang dilaksanakan oleh dosen prodi Manajemen Universitas Pamulang, memiliki target untuk membantu warga melalui kemitraan dengan meningkatkan kegiatan UMKM di daerah ini. Sehingga, wirausaha maupun pedagang terbiasa menggunakan fasilitas online yang nantinya akan mendukung kegiatan jual beli online serta dapat memenuhi kebutuhan hidup mereka. Nilai lain yang didapat adalah dengan melihat peluang pasar, Susanto, J. (2012). Proses marketing dapat dimulai dari jejaring terdekat sampai pada jejaring pemasaran dalam lingkup yang lebih luas melalui media online menurut Putranto, A. T., Widodo, A. S., Hanny, R., Septiani, F., \& Armansyah, A. (2020).

Tempat pelaksanaan kegiatan Pengabdian kepada Masyarakat (PkM) oleh dosen Universitas Pamulang yang bertempat di Jl. Raya Kabasiran km.2, Kecamatan Parung Panjang, Kab Bogor (16360). Kegiatan ini berisi tentang pembinaan usaha secara online yang disampaikan oleh para pemateri dimana telah dijelaskan gambaran secara singkat bagaimana implikasi ilmu manajemen pemasaran dan manajamen keuangan diterapkan secara langsung dalam kehidupan sehari-hari.

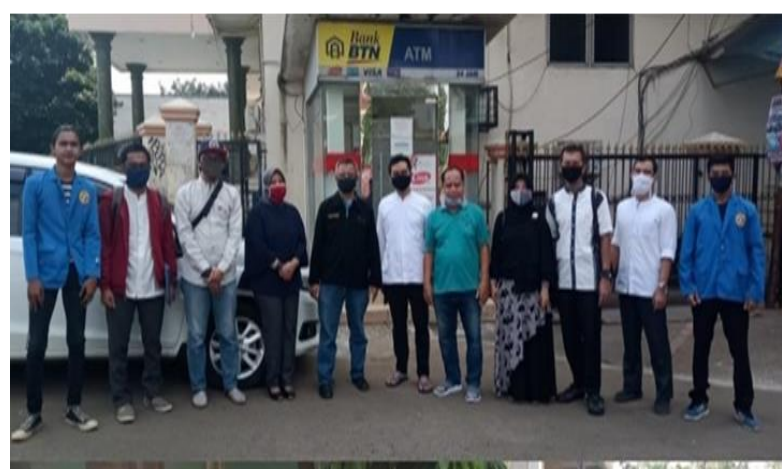

Gambar 1. Foto Bersama Anggota PKM

\section{METODE}

Pelatihan pembinaan usaha secara online untuk meningkatkan pemasaran di masa pandemic covid-19 pada warga yang berwirausaha ini dibagi dalam 2 metode besar. Kedua metode tersebut adalah metode pra-pelatihan dan metode pelaksanaan kegiatan pelatihan.

Metode pra-pelatihan berisi beberapa kegiatan, antara lain: cara survey dan kami mengunjungi warga yang berwirausaha beralamat di Jl. Raya Kabasiran km.2, Kecamatan Parung Panjang, Kab Bogor (16360) serta memberikan pembinaan usaha secara online untuk meningkatkan pemasaran di masa pandemic covid -19.

$$
\text { Kegiatan dalam bagian ini }
$$
membutuhkan waktu kurang lebih dua hingga tiga bulan. Pelaksanaan kegiatan pembinaan berisi antara lain: ceramah, praktek dalam menggunakan sosial media serta tanya jawab antara pemateri dengan perwakilan dari peserta. Kegiatan membutuhkan waktu 3 hari yang dilaksanakan pada hari Sabtu sampai Senin pada tanggal 16 - 18 Mei 2020 dengan memberikan pembinaan usaha secara online untuk meningkatkan pemasaran di masa pandemic covid -19 .

\section{HASIL DAN PEMBAHASAN}

Hasil kegiatan PkM secara garis besar mencakup beberapa komponen sebagai berikut: 1. Keberhasilan target jumlah peserta pembinaan 2. Ketercapaian tujuan 
pembinaan 3. Ketercapaian target materi yang telah direncanakan 4. Kemampuan peserta dalam penguasaan materi pembinaan dan implementasi manajemen pemasaran sebagai persiapan meningkatkan pemasaran produk secara online di masa pandemic covid-19 yang beralamat di Jl. Raya Kabasiran km.2, Kecamatan Parung Panjang, Kab Bogor (16360) seperti direncanakan sebelumnya adalah ada 30 warga yang menjadi peserta di dalam pelaksanaan kegiatan tersebut. Dengan demikian dapat dikatakan bahwa target peserta tercapai $100 \%$. Angka tersebut menunjukkan bahwa kegiatan PkM dilihat dari jumlah peserta yang mengikuti dapat dikatakan sukses. Ketercapaian tujuan pembinaan dan implementasi manajemen pemasaran sebagai persiapan meningkatkan pemasaran secara online untuk berwirausaha secara umum sudah baik. Sehingga, dapat disimpulkan bahwa tujuan kegiatan dapat tercapai dengan baik. Ketercapaian target materi pada kegiatan PkM cukup baik, karena materi pembinaan dan implementasi manajemen pemasaran sebagai persiapan meningkatkan pemasaran secara online, menuju peningkatan pemasaran melalui online dengan menjadi wirausaha yang mandiri dan handal telah dapat disampaikan secara keseluruhan. Secara keseluruhan kegiatan pembinaan dan implementasi manajemen pemasaran sebagai persiapan menuju peningkatan pemasaran secara online dengan berwirausaha untuk meningkatkan perekonomian warga di Jl. Raya Kabasiran km.2, Kecamatan Parung Panjang, Kab Bogor (16360).

\section{PENUTUP}

Program Pengabdian kepada Masyarakat (PkM) berupa pembinaan dan implementasi manajemen pemasaran sebagai persiapan menuju peningkatan pemasaran secara online di masa pandemic covid-19 terutama bagi warga yang berwirausaha dapat diselenggarakan dengan baik dan berjalan dengan lancar sesuai dengan rencana kegiatan yang telah disusun. Kegiatan ini mendapat sambutan yang hangat, terbukti dengan keaktifan peserta mengikuti pendampingan dengan tidak meninggalkan tempat sebelum waktu pembinaan dan implementasi berakhir.

Berdasarkan evaluasi yang telah dilakukan dapat diajukan beberapa saran sebagai berikut: 1). Waktu pelaksanaan kegiatan pengabdian perlu ditambah agar tujuan kegiatan dapat tercapai sepenuhnya, tetapi dengan konsekuensi penambahan biaya pelaksanaan. Oleh karena itu biaya PkM sebaiknya tidak sama antara beberapa tim pengusul proposal, mengingat khalayak sasaran yang berbeda pula. 2). Adanya kegiatan lanjutan yang berupa pelatihan sejenis selalu diselenggarakan secara periodik sehinga dapat meningkatkan wawasan serta kemampuan bagi warga di Jl. Raya Kabasiran km.2, Kecamatan Parung Panjang, Kab Bogor (16360).

\section{DAFTAR PUSTAKA}

Affandi, A. (2020). Optimization of MSMEs Empowerment in Facing Competition in the Global Market during the COVID19 Pandemic Time. Systematic Reviews in Pharmacy, 11(11), 15061515.

Ahidin, U., Abidin, A. Z., Halomoan, Y. K., Permatasari, R. J., \& Sunarsi, D. (2020). Pelatihan Dasar Kepemimpinan Milenial Karang Taruna Kelurahan Pamulang Barat. BAKTIMAS: Jurnal Pengabdian pada Masyarakat, 2(1), 7276.

Ajimat, A., Sunarsi, D., \& Sidiq, F. (2020). Berwirausaha Memanfaatkan Media Sosial Pada Daerah Sepatan. ADI Pengabdian Kepada Masyarakat, 1(1), 69-76.

Akbar, Irfan Rizka,. (2018) Analisis Kebijakan Kepala Sekolah Dalam Upaya Meningkatkan Kompetensi Guru (Study Kasus Pada Smk Muhammadiyah Parung). Masters thesis, Universitas Pamulang.

Anderson, R., \& Joanna, K. (2009). Equity in Health Service, Emperical Analysis.

Effendy, A. A., \& Sunarsi, D. (2020). Persepsi Mahasiswa Terhadap Kemampuan Dalam Mendirikan UMKM Dan Efektivitas Promosi Melalui Online Di Kota Tangerang Selatan. Jurnal Ilmiah MEA (Manajemen, Ekonomi, \& Akuntansi), 4(3), 702-714. 
Gumilar, I., Sunarsi, D. (2020). Comparison of financial performance in banking with high car and low car (Study of banks approved in the kompas 100 index for the period 2013-2017). International Journal of Psychosocial Rehabilitation. Volume 24 - Issue 7

Guntur Setiawan. 2004. "Impelemtasi dalam Birokrasi Pembangunan". Balai Pustaka. Jakarta.

Hidayat, D., Prabowo, B., \& Anwar, S. (2020). Organizational Leadership and Conflict in Human Resource Management Review. Solid State Technology, 63(6), 1372-1381.

Maddinsyah, A., Sunarsi, D., Hermawati, R., Pranoto. (2020). Analysis of location selection effect on the user decision that influcence the success of the service business of micro, small and medium enterprise (MSME) in bandung timur region. International Journal of Advanced Science and Technology. Vol. 29 No. 06

Munarsih, (2019). Analisis Strategi Pelaksanaan Pelayanan Pendidikan pada SDIT Bina Cendekia - Depok. Jurnal Kompetitif, Vol 2, No 3, 136-155.

Notoatmodjo, S. (2003). Pengembangan Sumber Daya Manusia, Jakarta: PT. Rineka Cipta.

Nurdin Usman. 2002. "Konteks Implementasi Berbasis Kurikulum". Grasindo. Jakarta.

Purwanti, P., Sarwani, S., \& Sunarsi, D. (2020). Pengaruh Inovasi Produk Dan Brand Awareness Terhadap Keputusan Pembelian Konsumen Pada Pt. Unilever Indonesia. Inovasi, 7(1), 2431.

Putranto, A. T., Widodo, A. S., Hanny, R., Septiani, F., \& Armansyah, A. (2020). Melalui PkM Universitas Pamulang: Mari Kita Tingkatkan Jejaring Pemasaran POSYANTEK dalam Menyongsong Era Industri 4.0. Abdi Laksana, 1(2).

Rozi, A., Agustin, F., Hindriari, R., Rostikawati, D., \& Akbar, I. R. (2020). The Effect Of Leadership On Employee Performance at PT. Stella Satindo In Jakarta. HUMANIS (Humanities, Management and Science Proceedings), 1(1).
Sarwani, S., Akbar, I. R., Handoko, A. L., \& Ilham, D. (2020). Pengaruh Pelatihan dan Motivasi terhadap Produktivitas Kerja Karyawan pada PT. Lion Mentari Airlines Bandara Internasional Soekarno Hatta Cengkareng. Jurnal Ilmu Komputer dan Bisnis, 11(2a), 91100.

Sidharta, I., Priadana, M. S., \& Affandi, A. (2019). Innovative behavior: the study of intellectual capital effect on creative fashion industry in Bandung, Indonesia. Problems and Perspectives in Management, 17(4), 404.

Sofyan, S., Prasada, D., \& Akbar, I. R. (2020). Pengaruh Motivasi, Lingkungan Kerja dan Kepuasan Kerja Terhadap Kinerja Guru SMP/MTs Muhammadiyah Cabang Sawangan. Jurnal Ilmu Komputer dan Bisnis, Volume 11, Issue 2a, Pages 44-55

Stoner, J. A., Freeman, R. E., \& Gilbert, D. R. JR.(2000). Management.

Sunarsi, D., \& Asmalah, L. (2018). Pelatihan Manajemen Pengembangan Diri Bagi Penerima Beasiswa RZIS UGM Dan Dompet Shalahuddin Jogjakarta. Jurnal Pengabdian Dharma Laksana, 1(1), 5160.

Sunarsi, D., Kustini, E., Lutfi, A. M., Fauzi, R. D., \& Noryani, N. (2019). Penyuluhan Wirausaha Home Industry Untuk Meningkatkan Ekonomi Keluarga Dengan Daur Ulang Barang Bekas. BAKTIMAS: Jurnal Pengabdian pada Masyarakat, 1(4), 188-193.

Sunasi, D., Kusjono, G., \& Nuryana, I. (2019). Pelatihan Manajemen Penguasaan Kelas Dan Pembuatan Bahan Ajar Bagi Tenaga Pengajar Sukarela Taman Belajar Kreatif Mekarsari. Jurnal Pengabdian Dharma Laksana, 2(1), 4144.

Susanto, J. (2012). Pengaruh Pemasaran Online. Harga dan Pelayanan Terhadap Keputusan Pembelian (Studi pada Website www. pagarkanopi. com). Tesis, Universitas Pamulang. 